\title{
Phytochemical Screening and Larvicidal Evaluation of Phyto-synthesized Silver Nanoparticles using Palmyra Palm Sprout Extract
}

\author{
Wilson Lamayi Danbature, Zaccheus Shehu, Muhammad Mustapha Adam*, Ahmed Mohammed \\ Bello \\ Department of Chemistry, Faculty of Science, Gombe State University \\ Gombe State University, P.M.B 127, Tudun Wada Gombe, Gombe State, Nigeria. 760214 \\ *Email: mmadam1042@gmail.com
}

\begin{abstract}
One of the objectives of nanotechnology is to synthesize effective nanoinsecticides in a bid to reduce the prevalence of the numerous diseases caused by mosquitoes. This synthesis is even more vital in cases where phytochemicals from plant extracts are used as reducing agents. This study aims to determine the phytochemicals present in Palmyra (Borassus aethiopum) sprout extract, perform green synthesis of silver NPs with the sprout extract, and spectroscopic investigation using FT-IR and UV-Visible spectrophotometers, in addition to the main aim of evaluating the AgNPs' applications as a nano-larvicide. For this study, a total of ten phytochemical analyses was performed. Subsequently, the sprout extract was used as a reducing agent in the synthesis of silver nanoparticles (AgNPs). Characterization with Fourier transform infrared and Ultraviolet-visible spectrometry was then carried out to confirm the synthesis. In addition, the AgNPs were further analyzed for larvicidal potency against $1^{\text {st }}, 2^{\text {nd }}, 3^{\text {rd }}$ and $4^{\text {th }}$ instars Culex quinquefasciatus mosquito larvae, at interval concentrations of $5,10,20,25$, and $50 \mathrm{ppm}$. The results confirmed the presence of alkaloids, flavonoids, saponins, coumarins, glycosides, tannins, phenols as well as quinines, however, sterols, steroids, and terpenoids were not detected. The $\mathrm{LC}_{50}$ and $\mathrm{LC}_{90}$ values discovered to be $9.103 \mathrm{ppm}$ and $134.463 \mathrm{ppm}$ with a correlation of 0.815 , as well as $10.316 \mathrm{ppm}$ and $118.810 \mathrm{ppm}$ with a correlation of 0.801 , for the $1^{\text {st }}$ and $2^{\text {nd }}$ instars, respectively. Meanwhile, the $3^{\text {rd }}$ and $4^{\text {th }}$ instars had $L_{50}$ and $L C_{90}$ values of $17.585 \mathrm{ppm}$ and $179.052 \mathrm{ppm}$, respectively, with a correlation of 0.807 . This study provides a basis for extracting and analyzing the reduction potential of the phytochemicals present in the sprout extract, as well as the application of AgNPs, in controlling the mosquito larvae population.
\end{abstract}

Keywords: AgNPs; Culex quinquefasciatus; larvicidal activity; Palmyra palm; phytochemical screening

Article History: Received 27 September 2020; Received in revised form 30 October 2020; Accepted 22 November 2020; Available online 30 December 2020

How to Cite This Article: Danbature WL, Shehu Z, Adam MM, Bello AM. 2020. Phytochemical screening and larvicidal evaluation of phyto-synthesized silver nanoparticles using Palmyra palm sprout extract. Biogenesis: Jurnal Ilmiah Biologi. vol 8(2): 126-132. doi: https://doi.org/10.24252/bio.v8i2.17581.

\section{INTRODUCTION}

Phytochemical screening is a crucial step in the discovery of bioactive compounds (Altemimi et al., 2017), while a report by Kwaji et al. (2018) showed some phytochemicals have been known to exhibit biological properties. Phytochemicals are natural, usually bioactive compounds, often found in plants as primary or secondary components (Chikara et al., 2018). The primary compounds are utilized exclusively used by plants, hence, the secondary compounds are more fascinating for studies. Prior to modern science, plants were consumed without any knowledge of the health benefits or side effects of the component compounds (Ma \& Zhang, 2017).

Borassus is a genus comprising of six species of fan palm, found in tropical Africa (Salako et al., 2015; Siebert \& Struwig, 2019),
Asia (Eagleton, 2016; Pipatchartlearnwong et al., 2017; Sakulsathaporn et al., 2017) and New Guinea (Sudhakara et al., 2013; Pangau-Adam \& Muehlenberg; 2014; Jerry, 2018). Borassus aethiopum, an edible crop with highly nutritious fruits and sprouts, commonly called Palmyra or Palmyra palm, is one of these species (Ali et al., 2010; Srinivasababu et al., 2014). However, previous studies provide better insights on Borassus flabellifer. This species has a higher carbohydrate, fiber, amino acids, and protein content, contains essential phytochemicals, also exhibits significant antibacterial activity at the different parts of the plant such as root (Sahni et al., 2014; Aziz et al., 2016), leaves (Jamkhande et al., 2016; Sarmini \& Premaratne, 2018), fruit (Vijayakumari et al., 2014; Singchai et al., 
2015), and seeds (Arunachalam et al., 2011; Rahman et al., 2020).

Meanwhile, Culex quinquefasciatus is a mosquito vector responsible for various diseases, including bancroftian filarial parasite, the major cause of human lymphatic filariasis (Sutthanont et al., 2019). Velayutham et al. (2016) and Morejón et al. (2018) reported silver nanoparticles to have larvicidal properties, while Awwad \& Salem (2012) the metal has been widely recognized due to the numerous applications in nanotechnology. Furthermore, AgNPs are one of the earliest synthesized nanoparticles and have long been used for medical purposes. However, the conventional methods of synthesis involve chemicals with harmful effects on humans and the environment (Chikkanna \& Neelagund, 2018). Recently, alternative, environmentally friendly and cost effective techniques were developed to replace chemical and physical reduction methods (Kalpana \& Rajeswari, 2018). This study therefore, aims to determine the phytochemicals present in Palmyra sprout extract, perform green synthesis of silver NPs with the sprout extract, and spectroscopic investigation using FT-IR and UV-Visible spectrophotometers, in addition to the main aim of evaluating the AgNPs' applications as a nano-larvicide. Palmyra palm sprout extract exhibits significant larvicidal potency, while its nanoparticles can be a better alternative to available chemicals to control and against mosquitos.

\section{MATERIALS AND METHODS}

Sample collection and preparation. Palmyra sprouts were collected from Gombe metropolis, packaged in polyethylene bags, transported to the General Chemistry Laboratory II in Gombe State University, and then identified in the Laboratory of Botany, Department of Biological Science. Subsequently, the sprouts were washed with clean tap water, followed by distilled water, cut into tiny pieces, crushed using mortar and pestle, and then weighed. About $20 \mathrm{~g}$ of the sample was then mixed with $250 \mathrm{ml}$ of distilled water and heated with a hot plate at $60^{\circ} \mathrm{C}$, for $30 \mathrm{~min}$. This was followed by cooling and filtering, using Whatman No.1 filter paper. The filtrate was subjected to phytochemical screening, and stored at $4{ }^{\circ} \mathrm{C}$, prior to further analyses (Sivakumar, 2019).

Phytochemical analyses. Test for phenols and tannins (Lead acetate test) was performed by adding $0.5 \mathrm{ml}$ of $1 \%$ lead acetate solution to $10 \mathrm{mg}$ of the sprout extract. The formation of a white precipitate indicated the presence of tannins and phenolic compounds (Gibbs, 1974; Bhatt \& Dhyani, 2012). Test for saponins was carried out by diluting $0.5 \mathrm{mg}$ of extract in 20 $\mathrm{ml}$ distilled water, and shaking in a graduated cylinder for $15 \mathrm{~min}$. The formation of emulsion up to $1 \mathrm{~cm}$ long, confirmed the presence of saponins (Odebiyi \& Sofowora, 1978; Bhatt \& Dhyani, 2012). Test for coumarins was performed by adding $10 \%$ sodium hydroxide to $2 \mathrm{ml}$ of the extract. The formation of yellow precipitate indicated the presence of coumarins (Schönberg \& Aziz, 1955; Ryu \& Yook; 1967). Test for quinones was carried out by treating 2 $\mathrm{ml}$ of the plant extract with $5 \mathrm{ml}$ of $\mathrm{HCl}$. The formation of a yellow precipitate indicated the presence of quinone (Loganathan et al., 2017). For flavonoids test, $1 \mathrm{ml}$ of the extract was treated with $1 \mathrm{ml}$ of sulphuric acid. The formation of orange coloration confirmed the presence of a flavonoid (Tyagi, 2017). Test for glycosides was performed by dissolving $1 \mathrm{ml}$ of the extract in distilled water and then adding aqueous $\mathrm{NaOH}$ solution. The formation of yellow coloration is indicative of glycoside presence (Jagessar, 2017). Test for steroids and sterols (Salkowski's test) was used $2 \mathrm{ml}$ of extract dissolved in $2 \mathrm{ml}$ of chloroform and equal volume of concentrated sulphuric acid was added along the sides of the test tube. The upper layer turned red and lower layer turned yellow with green fluorescence, indicating the presence of the steroids and sterols in the extract (Singh \& Kumar, 2017). Test for terpenoids was performed by treating $2 \mathrm{ml}$ of the extract with $2 \mathrm{ml}$ of acetic acid, followed by adding $2 \mathrm{ml}$ of sulphuric acid. The formation of deep red coloration confirmed the presence of terpenoids (Harborne, 1978; Trease \& Evans, 1989). Test for alkaloid was carried out by adding $3 \mathrm{ml}$ of $1 \% \mathrm{HCl}$ to $3 \mathrm{ml}$ of the extract stirred on water bath for $20 \mathrm{~min}$. The mixture 
was then cooled and used to perform the Wagner and Mayer's test. A total of $1 \mathrm{ml}$ of Wagner reagent was added drop-wise to the mixture and a reddish brown precipitate indicated alkaloid presence, while Mayer test was performed by adding Mayer reagent dropwise to $1 \mathrm{ml}$ of the mixture in a test tube and a greenish coloration or cream precipitate confirmed the presence of alkaloid (Harborne, 1978; Trease \& Evans, 1989).

Synthesis of silver nanoparticles. A total of $100 \mathrm{ml}$ of aqueous Palmyra sprout extract was mixed with $500 \mathrm{ml}$ of $0.01 \mathrm{M}$ silver nitrate $\left(\mathrm{AgNO}_{3}\right)$ in a $1 \mathrm{~L}$ erlenmeyer flask. The mixture was then boiled at $600^{\circ} \mathrm{C}$ until the color changed to dark brown and a precipitate was formed. Subsequently, the mixture was left to stand for $24 \mathrm{~h}$ at $27^{\circ} \mathrm{C}$, to enable the silver nanoparticles settle at the bottom. This was followed by filtration using Whatman No. 1 filter paper. The residue was then dried at $105^{\circ} \mathrm{C}$ in a hot air oven for 6 hours to obtain fine AgNPs (Banne et al., 2017; Razali et al., 2017).

\section{Ultraviolet-visible} spectroscopic

analysis. For this characterization, two clean cuvettes, one filled with distilled water (blank solvent), and the other with the filtrate obtained from the AgNPs, were placed in the spectrometer. Subsequently, the absorbance values were recorded at intervals of $100 \mathrm{~nm}$, from $200 \mathrm{~nm}$ to $800 \mathrm{~nm}$, and a graph of absorbance against wavelength was plotted (Razali et al., 2017 with modification).

\section{Fourier transform infrared} spectroscopic analysis (FT-IR). This characterization technique was performed to study the phytochemicals involved in the phyto-synthesis of AgNPs. A mixture comprising about $99 \% \mathrm{KBr}$ and $1 \%$ NPs was crushed with a mortar and pestle and pelletized with a pelletizer and hydraulic press, then placed into FTIR sample holder and introduced into the infrared spectrophotometer (Sytu \& Camacho, 2018).

Larvicidal bioassay. The AgNPs' larvicidal activity against Culex quinquefasciatus larvae was evaluated, as described by Lamayi et al. (2020). Culex quinquefasciatus larvae were obtained from stagnant water in Gombe metropolis and divided into three groups based on growth stage. The third and the fourth instars were group in one because of the difficulty to obtain homogenous population. Meanwhile, a 100 ppm AgNPs stock solution was prepared, and used to produce other required subsequent concentrations through serial dilution. A paper cup was then filled with $100 \mathrm{ml}$ of distilled water and used as the control sample. Subsequently, $100 \mathrm{ml}$ of 5, 10, 20, 25, and 50 ppm AgNP solutions were prepared and evaluated for larvicidal activity on all the instars, and the larval mortality was recorded after 24 hours of exposure.

\section{RESULTS AND DISCUSSION}

Phytochemical screening. Based on the results of phytochemical screening, alkaloids, saponins, flavonoids, and coumarins, were present in considerable quantity, glycosides and quinones were present in minute quantity, while terpenoids and steroids were absent (Table 1).

Table 1. Phytochemical screening of Palmyra palm.

\begin{tabular}{ll}
\hline Metabolites & Result \\
\hline Alkaloids & ++ \\
Saponins & ++ \\
Flavonoids & ++ \\
Glycosides & + \\
Coumarins & ++ \\
Quinones & + \\
Steroids and Sterols & - \\
Terpenoids & - \\
Phenols and tannins & + \\
\hline Notes: -not detected; +present; ++much present
\end{tabular}

A similar study by Alamelumangai et al (2014) on Borassus flabellifer Linn, reported the presence of flavonoids, saponins, glycosides, tannins and terpenoids.

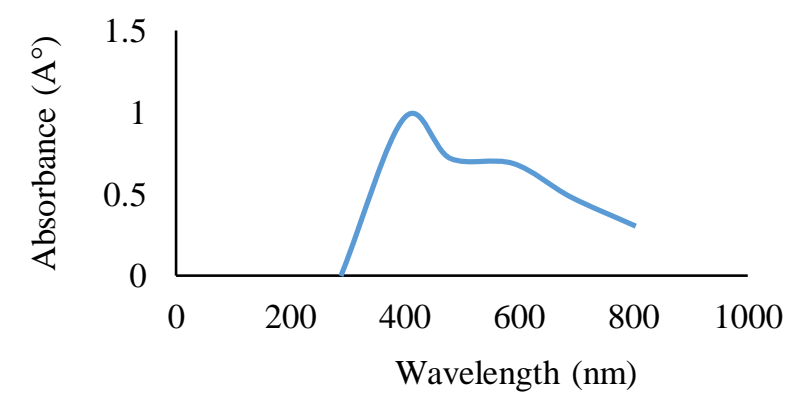

Fig. 1. UV-Visible spectrum for silver nanoparticles (AgNPs). 


\section{Ultraviolet-visible}

spectroscopic analysis. Fig. 1 shows the UV-Vis spectrum of AgNPs obtained by plotting absorbance against wavelength. The maximum absorbance, 0.968 was recorded at a wavelength of $390 \mathrm{~nm}$, near the wavelength for violet color. This corresponds to the color change of the solution from pale yellow to dark brown, due to the excitation and vibration of bio-reducing and stabilizing agents. Elamawi et al. (2018) also

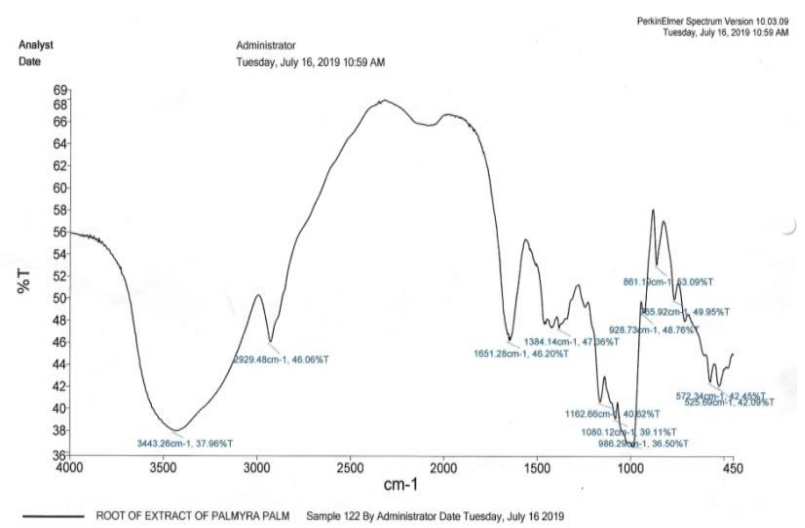

Fig. 2. FT-IR spectrum for the sprout extract of Palmyra palm.

Meanwhile, the major absorption bands in the raw extract's spectrum were attributed to various functional groups. The peak at 3443.26 $\mathrm{cm}^{-1}, 37.96 \% \mathrm{~T}$ is attributed to $\mathrm{O}-\mathrm{H}$, - $\mathrm{NH}$ group of terpenoids, alkaloids other alcohols and phenols, the peak at $2929.48 \mathrm{~cm}^{-1}, 46.06 \% \mathrm{~T}$ is probably due to $\mathrm{sp} 3 \mathrm{C}-\mathrm{H}$ bond stretching, the reported a similar maximum absorption value of $385 \mathrm{~nm}$, for AgNPs.

Fourier transform infrared spectroscopic analysis (FT-IR). This was performed to study the interactions between the Palmyra sprout extract and aqueous silver nitrate salt. Fig. 2 and Fig. 3 show the FT-IR spectra of the extract and the AgNPs, respectively.

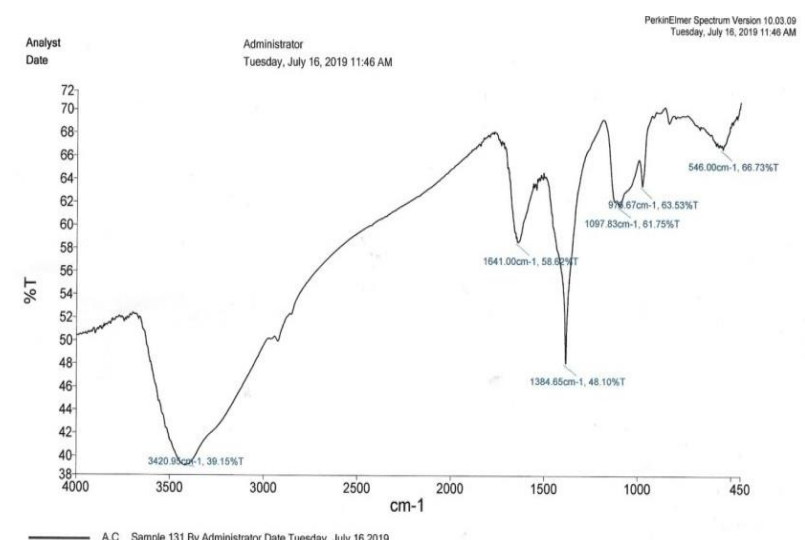

Fig. 3. FT-IR spectrum for AgNPs.

peak at $1651.28 \mathrm{~cm}^{-1}, 48.20 \% \mathrm{~T}$ is possibly due to $\mathrm{C}=\mathrm{O}$ or $\mathrm{C}=\mathrm{N}$ groups in alkaloids and terpenoids, while the peaks at $1384.14 \mathrm{~cm}^{-1}$, $47.36 \% \mathrm{~T}$ and $1162.66 \mathrm{~cm}^{-1}, 40.62 \% \mathrm{~T}$ are probably due to $\mathrm{C}-\mathrm{H}$ rock bending vibration and $\mathrm{C}-\mathrm{C}$ stretching in terpenoids, respectively.

Table 2. Larvicidal activity of synthesized silver nanoparticles.

\begin{tabular}{|c|c|c|c|c|c|c|c|c|}
\hline \multirow{2}{*}{ Larvae } & \multirow{2}{*}{ Conc.(ppm) } & \multirow{2}{*}{$\%$ mortality } & \multirow{2}{*}{$\mathrm{LC}_{50}$} & \multirow{2}{*}{$\mathrm{LC}_{90}$} & \multicolumn{2}{|c|}{$95 \%$ Confidence } & \multirow{2}{*}{$X^{2}$} & \multirow{2}{*}{$\mathrm{R}$} \\
\hline & & & & & $\mathrm{LC}_{50}$ & $\mathrm{LC}_{90}$ & & \\
\hline \multirow[t]{5}{*}{$1^{\text {st }}$ instar } & 5 & 45 & \multirow[t]{5}{*}{6.042} & \multirow[t]{5}{*}{118.144} & $3.354-$ & $66.672-$ & \multirow[t]{5}{*}{0.654} & \multirow[t]{5}{*}{0.863} \\
\hline & 10 & 60 & & & 8.472 & 362.001 & & \\
\hline & 20 & 70 & & & & & & \\
\hline & 25 & 75 & & & & & & \\
\hline & 50 & 80 & & & & & & \\
\hline \multirow{5}{*}{$2^{\text {nd }}$ instar } & 5 & 30 & \multirow[t]{5}{*}{10.490} & \multirow[t]{5}{*}{86.565} & $8.165-$ & 59.112- & \multirow[t]{5}{*}{1.941} & \multirow[t]{5}{*}{0.855} \\
\hline & 10 & 50 & & & 12.781 & 158.833 & & \\
\hline & 20 & 70 & & & & & & \\
\hline & 25 & 70 & & & & & & \\
\hline & 50 & 80 & & & & & & \\
\hline $3^{\text {rd }} / 4^{\text {th }}$ & 5 & 25 & \multirow[t]{5}{*}{20.263} & \multirow[t]{5}{*}{326.146} & $15.886-$ & $120.155-$ & \multirow[t]{5}{*}{0.184} & \multirow[t]{5}{*}{0.923} \\
\hline \multirow[t]{4}{*}{ instar } & 10 & 38 & & & 26.925 & 1325.843 & & \\
\hline & 20 & 50 & & & & & & \\
\hline & 25 & 55 & & & & & & \\
\hline & 50 & 65 & & & & & & \\
\hline
\end{tabular}


The numerous peaks formed after the synthesis of the AgNPs (Fig. 3). The major absorption bands occurred at $3420.95 \mathrm{~cm}^{-1}$, $39.155 \% \mathrm{~T}, \quad 1641.00 \mathrm{~cm}^{-1}, 58.62 \% \mathrm{~T}$, $1384.64 \mathrm{~cm}^{-1}, 48.10 \%$ T. Furthermore, the disappearance of peaks at $2929.48 \mathrm{~cm}^{-1}$, $46.06 \% \mathrm{~T}, 986.29 \mathrm{~cm}^{-1}, 36.50 \% \mathrm{~T}$, as well as the other bands between $450 \mathrm{~cm}^{-1}$ to $1500 \mathrm{~cm}^{-1}$, confirms the formation of silver nanoparticles as previously explained by Danbature et al. (2020a).

Larvicidal activity. Table 2 is the result of the larvicidal activity assay of silver nanoparticles at various concentrations $(5,10$, $20,25,50)$ against the first, second and third/fourth instars of mosquito larvae. These evaluations were repeated twice and the average values were computed. For the first instar, the $\mathrm{LC}_{50}$ (lethal concentration at 50\%) was discovered to be $6.042 \mathrm{ppm}$, while the $\mathrm{LC}_{90}$ (lethal concentration at $90 \%$ ) was found to be $118.144 \mathrm{ppm}$, with a correlation of 0.863 . Meanwhile, for the second instar, the $\mathrm{LC}_{50}$ and $\mathrm{LC}_{90}$ values were discovered to be $10.490 \mathrm{ppm}$ and $86.565 \mathrm{ppm}$, respectively, with a correlation of 0.855 . In addition, the $\mathrm{LC}_{50}$ and $\mathrm{LC}_{90}$ for the third/fourth instar, were found to be $20.263 \mathrm{ppm}$ and $326.146 \mathrm{ppm}$, respectively, with a correlation of 0.923 . The nanoparticles obtained from this synthesis were discovered to be less active compared to the report by Danbature et al. (2020b), and to be more active compared to the study by Shehu et al. (2020), at all concentrations. It is reasonable to state that the mortality rates were positively correlated with the concentration of AgNPs. Bioactive constituents of Palmyra are proving valuable compounds as an ideal eco-friendly approach in controlling the mosquito larvae population.

\section{CONCLUSION}

The phytochemical screening of Borassus aethiopum sprout extract confirmed the presence of seven out of the nine secondary compounds studied. From this evaluation, alkaloids, saponins, glycosides, quinones, phenols, tannings, coumarins and flavonoids were discovered to be present within the extract, while terpenoids and sterols/steroids, were not detected. The detected phytochemicals were responsible for the reduction of $\mathrm{Ag}$ ion and the formation of silver nanoparticles. Furthermore, the FT-IR and UVVisible spectrophotometric characterizations confirmed the formation of AgNPs. The synthesized nanoparticles were also discovered to exhibit significant larvicidal potency, hence, there is a need to fully characterize the AgNPs and carry out further studies regarding the potential applications against the organism.

\section{REFERENCES}

Alamelumangai M, Dhanalakshmi J, Mathumitha M, Renganayaki RS, Muthukumaran P, Saraswathy N. 2014. In vitro studies on phytochemical evaluation and antimicrobial activity of Borassus flabellifer Linn against some human pathogens. Asian Pacific Journal of Tropical Medicine. vol 7(1): 182-185. doi: https://doi.org/10.1016/s1995-7645(14)602285.

Ali A, Alhadji D, Tchiegang C, Saïdou C. 2010. Physicochemical properties of Palmyra palm (Borassus aethiopum Mart.) fruits from northern Cameroon. Academic Journals. vol 4(3): 115-119. https://doi.org/10.5897/AJFS.9000231.

Altemimi A, Lakhssassi N, Baharlouei A, Watson DG, Lightfoot DA. 2017. Phytochemicals: Phytochemicals: Extraction, isolation, and identification of bioactive compounds from plant extract. Plants. vol 6(4): 1-23. doi: https://doi.org/10.3390/plants6040042.

Arunachalam K, Saravanan S, Parimelazhagan T. 2011. Nutritional analysis and antioxidant activity of Palmyrah (Borassus flabellifer L.) seed embryo for potential use as food source. Food Science and Biotechnology. vol 20(1): 143-149. doi: https://doi.org/10.1007/s10068-011-0020-y.

Awwad AM, Salem NM. 2012. Green synthesis of Silver nanoparticles by mulberry leaves extract. Nanoscience and Nanotechnology. vol 2(4): 125128. doi: https://doi.org/10.5923/j.nn.20120204.06.

Aziz MA, Sarkar KK, Akter MI, Kabir AL, Roy DN. 2016. Assessment of neuropharmacological activities of Borassus flabellifer L. roots. Journal of Pharmacognosy and Phytochemistry. vol 5(5): 452-456.

Banne SV, Patil MS, Kulkarni RM, Patil SJ. 2017. Synthesis and characterization of silver nano particles for EDM applications. Materials Today: Proceedings. vol 4(11): 12054-12060. doi: https://doi.org/10.1016/j.matpr.2017.09.130.

Bhatt S, Dhyani S. 2012. Preliminary phytochemical screening of Ailanthus excelsa Roxb. International Journal of Current Pharmaceutical Research. vol 4(1): 87-89.

Chikara S, Nagaprashantha LD, Singhal J, Horne D, Awasthi S, Singhal SS. 2018. Oxidative stress and 
dietary phytochemicals: Role in cancer chemoprevention and treatment. Cancer Letters. vol 413: 122-134. doi: https://doi.org/10.1016/j.canlet.2017.11.002.

Chikkanna MM, Neelagund SE. 2018. Effect of sheep and goat fecal mediated synthesis and characterization of silver nanoparticles (AgNPs) and their antibacterial effects. Journal of Nanofluids. vol 7(2): 309-315. doi: https://doi.org/10.1166/jon.2018.1458.

Danbature WL, Abba E, Shehu Z, Adam MM. 2020a. Nanoinsecticidal efficacy of $\mathrm{Ag} / \mathrm{Ni}$ bimetallic nanoparticles (BMNPs) on lymphatic filariasis vector. Asian Journal of Research in Infectious Diseases. $\quad$ vol 5(2): 14-21. doi: https://doi.org/10.9734/ajrid/2020/v5i230163.

Danbature WL, Shehu Z, Yoro M, Adam MM. 2020 b. Nanolarvicidal effect of green synthesized Ag-Co bimetallic nanoparticles on Culex quinquefasciatus mosquito. Advances in Biological Chemistry. vol 10: 16-23. doi: https://doi.org/10.4236/abc.2020.101002.

Eagleton GE. 2016. Persistent pioneers; Borassus L. and Corypha L. in Malesia. Biodiversitas. vol 17(2): 716-732. https://doi.org/10.13057/biodiv/d170247.

doi:

Elamawi RM, Al-Harbi RE, Hendi AA. 2018. Biosynthesis and characterization of silver nanoparticles using Trichoderma longibrachiatum and their effect on phytopathogenic fungi. Egyptian Journal of Biological Pest Control. vol 28(28): 111. doi: https://doi.org/10.1186/s41938-018-00281.

Gibbs RD. 1974. Chemotaxonomy of Flowering Plants. Vol. 1. Montreal: McGill-Queen's University Press.

Harborne JB. 1978. Phytochemical methods. $3^{\text {rd }}$ ed. London: Chapman and Hall. pp. 60-135.

Jamkhande PG, Suryawanshi VA, Kaylankar TM, Patwekar SL. 2016. Biological activities of leaves of ethnomedicinal plant, Borassus flabellifer Linn.(Palmyra palm): An antibacterial, antifungal and antioxidant evaluation. Bulletin of Faculty of Pharmacy, Cairo University. vol 54(1): 59-66. doi: https://doi.org/10.1016/j.bfopcu.2016.01.002.

Jagessar RC. 2017. Phytochemical screening and chromatographic profile of the ethanolic and aqueous extract of Passiflora edulis and Vicia faba L. (Fabaceae). Journal of Pharmacognosy and Phytochemistry. vol 6(6): 1714-1721

Jerry A. 2018. A Comprehensive review on the medicinal properties of Borassus flabellifer. Journal of Academia and Industrial Research. vol 7(7): 93-97.

Kalpana VN, Rajeswari VD. 2018. A Review on green synthesis, biomedical applications, and toxicity studies of ZnO NPs. Bioinorganic Chemistry and Applications. $\quad$ vol 2018: $1-12$. https://doi.org/10.1155/2018/3569758.

Kwaji A, Adamu HM, Chindo IY, Atiko R. 2018. Isolation, characterization and biological properties of betulin from Entada africana Guill. and Perr.
(Mimosaceae). Journal of Applied and Advanced Research. vol 3(1): 28-31. doi: http://dx.doi.org/10.21839/jaar.2018.v312.138.

Lamayi WD, Shehu Z, Mai AJ, Magaji B, Adam MM, Bunu MA. 2020. Green synthesis, characterization and larvicidal Activity of $\mathrm{Cu} / \mathrm{Ni}$ bimetallic nanoparticles using fruit extract of Palmyra palm. International Journal of Chemistry and Materials Research. vol 8(1): 20-25. doi: https://doi.org/10.18488/journal.64.2020.81.20.25.

Loganathan V, Devi KM, Selvakumar P. 2017. A study of the physico-chemical and phytochemical parameters of leaves of Mallotus rhamnifolius. International Journal of Pharmacognosy and Phytochemical Research. vol 9(6): 858-863. doi: 10.25258/phyto.v9i6.8191.

Ma ZF, Zhang H. 2017. Phytochemical constituents, health benefits, and industrial applications of grape seeds: A mini-review. Antioxidants. vol 6(3): 1-11. doi: https://doi.org/10.3390/antiox6030071.

Morejón B, Pilaquinga F, Domenech F, Ganchala D, Debut A, Neira M. 2018. Larvicidal activity of silver nanoparticles synthesized using extracts of Ambrosia arborescens (Asteraceae) to control Aedes aegypti L. (Diptera: Culicidae). Journal of Nanotechnology. $\quad$ vol 2018: $1-8$. https://doi.org/10.1155/2018/6917938.

Odebiyi OO, Sofowora EA. 1978. Phytochemical screening of Nigerian medicinal plants II. Lloydia. vol 41(3): 234-246.

Pangau-Adam M, Muehlenberg M. 2014. Palm species in the diet of the northern cassowary (Casuarius unappendiculatus) in Jayapura region, Papua, Indonesia. Palms. vol 58(1): 19-26.

Pipatchartlearnwong K, Swatdipong A, Vuttipongchaikij S, Apisitwanich S. 2017. Genetic evidence of multiple invasions and a small number of founders of Asian Palmyra palm (Borassus flabellifer) in Thailand. BMC Genetics. vol 18(1): 1-8. doi: https://doi.org/10.1186/s12863-017-0554-y.

Rahman SS, Yasmin N, Kamruzzaman M, Islam MR, Karim MR, Rouf SM. 2020. Anti-hyperglycemic effect of the immature endosperm of sugar palm (Borassus flabellifer) fruit on type 2 diabetes mellitus patients-a case study. Diabetes \& Metabolic Syndrome: Clinical Research \& Reviews. vol 14(5): 1317-1322. doi: https://doi.org/10.1016/j.dsx.2020.06.055.

Razali NL, Shah NZAM, Morsin M, Noh FHM, Salleh MM. 2017. Seed-mediated synthesis of gold nanorods with variation of silver nitrate (AgNO3) concentration. Journal of Telecommunication, Electronic and Computer Engineering. vol 9(3-8): 123-127.

Ryu KS, Yook CS. 1967. Studies on the coumarins of the root of Angelica gigas NAKAI (I). Yakhak Hoeji. vol 11(3): 22-26.

Sahni C, Shakil NA, Jha V, Gupta RK. 2014. Screening of nutritional, phytochemical, antioxidant and antibacterial activity of the roots of Borassus 
flabellifer (Asian Palmyra Palm). Journal of Pharmacognosy and Phytochemistry. vol 3(4): 5868.

Sakulsathaporn A, Wonnapinij P, Vuttipongchaikij S, Apisitwanich S. 2017. The complete chloroplast genome sequence of Asian Palmyra palm (Borassus flabellifer). BMC Research Notes. vol 10(1): 1-7. doi: https://doi.org/10.1186/s13104-017-3077-8.

Salako VK, Assogbadjo AE, Adomou AC, Agbangla C, Glèlè Kakaï RL. 2015. Latitudinal distribution, cooccurring tree species and structural diversity of the threatened palm Borassus aethiopum (Arecaceae) in Benin, West Africa. Plant Ecology and Evolution. vol 148(3): 335-349. doi: https://doi.org/10.5091/plecevo.2015.1046.

Sarmini M, Premaratne S. 2018. Yield and nutritive value of palmyrah (Borassus flabellifer) leaves at different stages of maturity. Journal of Dry Zone Agriculture. vol 4(2): 49-56.

Schönberg A, Aziz G. 1955. Furo-chromones andcoumarins (X): On the Constitution of Prangenin. Journal of the American Chemical Society. vol 77(9): 2563-2564. doi: https://doi.org/10.1021/ja01614a068.

Shehu Z, Danbature WL, Magaji B, Adam MM, Bunu MA, Mai AJ, Yoro M. 2020. Green synthesis and nanotoxicity assay of Copper-Cobalt bimetallic nanoparticles as a novel nanolarvicide for mosquito larvae management. The International Journal of Biotechnology. vol 9(2): 99-104. doi: https://doi.org/10.18488/journal.57.2020.92.99.104

Siebert SJ, Struwig M. 2019. Borassus aethiopum Mart.(Arecaceae) in Limpopo province with a key to South African palms. Bothalia-African Biodiversity \& Conservation. vol 49(1): 1-6. doi: https://doi.org/10.4102/abc.v49i1.2374.

Singh V, Kumar R. 2017. Study of Phytochemical Analysis and Antioxidant Activity of Allium sativum of Bundelkhand Region. International Journal of Life Sciences Scientific Research. vol 3(6): 1451-1458.

Singchai B, Kansane K, Chourykaew B. 2015. Phytochemical screening and biological activities of Borassus flabellifer L. Asian Journal of Pharmaceutical and Clinical Research. vol 8(3): 151-153.

Sivakumar T. 2019. Phytochemical screening and gas chromatography-mass spectroscopy analysis of bioactive compounds and biosynthesis of silver nanoparticles using sprout extracts of Vigna radiata
L. and their antioxidant and antibacterial activity. Asian Journal of Pharmaceutical and Clinical Research. vol 12(2): 180-184. doi: http://dx.doi.org/10.22159/ajpcr.2019.v12i2.29253

Srinivasababu N, Kumar JS, Reddy KVK. 2014. Manufacturing and characterization of long palmyra palm/Borassus flabellifer petiole fibre reinforced polyester composites. Procedia Technology. vol 14: 252-259. doi: https://doi.org/10.1016/j.protcy.2014.08.033.

Sytu MRC, Camacho DH. 2018. Green synthesis of silver nanoparticles (AgNPs) from Lenzites betulina and the potential synergistic effect of AgNP and capping biomolecules in enhancing antioxidant activity. BioNanoScience. vol 8(3): 835-844. doi: https://doi.org/10.1007/s12668-0180548-x.

Sudhakara P, Kamala Devi AP, Venkata Prasad C, Obi Reddy K, Dong Woo L, Kim BS, Song, JI. 2013. Thermal, mechanical, and morphological properties of maleated polypropylene compatibilized Borassus fruit fiber/polypropylene composites. Journal of Applied Polymer Science. vol 128(2): 976-982.

Sutthanont N, Attrapadung S, Nuchprayoon S. 2019. Larvicidal activity of synthesized silver nanoparticles from Curcuma zedoaria essential oil against Culex quinquefasciatus. Insects. vol 10(1): $1-11$.

doi: https://doi.org/10.3390/insects10010027.

Trease GE, Evans WC. 1989. Pharmacognosy. $11^{\text {th }}$ ed. London: Bailliere Tindall. pp. 45-50

Tyagi T. 2017. Phytochemical screening of active metabolites present in Eichhornia crassipes (Mart.) Solms and Pistia stratiotes (L.): Role in ethanomedicine. Asian Journal of Pharmaceutical Education and Research. vol 6(4): 40-56.

Velayutham K, Ramanibai R, Umadevi M. 2016. Green synthesis of silver nanoparticles using Manihot esculenta leaves against Aedes aegypti and Culex quinquefasciatus. The Journal of Basic \& Applied Zoology. vol 74: 37-40. doi: https://doi.org/10.1016/j.jobaz.2016.06.002.

Vijayakumari, Vengaiah PC, Kiranmayi P. 2014. Physicochemical and functional characteristics of powder prepared from palmyra fruit pulp (Borassus flabellifer L.). International Journal of Current Microbiology and Applied Sciences. vol 3(9): 352356. 